\title{
PENGARUH METODE DAN KEMAMPUAN MOTORIK TERHADAP KETERAMPILAN JURUS TUNGGAL PENCAK SILAT
}

\author{
Zainul Johor ${ }^{1}$ \\ ${ }^{1}$ Program Studi Pendidikan Jasmani Kesehatan dan Rekreasi, Fakultas Ilmu Keolahrgaan Universitas \\ Negeri Padang.Jalan Prof.Dr.Hamka Air Tawar Barat, Padang, 25132, Indonesia. \\ Email:zainuljohor@fik.unp.ac.id ${ }^{1}$
}

\begin{abstract}
Abstrak
Mencermati data hasil belajar yang diperoleh mahasiswa FIK UNP yang mengambil mata kuliah pencak silat dasar dari 1380 mahasiswa, sebanyak 402 orang $(29,13 \%)$ yang tidak lulus dan nilai tunda sebanyak $278(20,14 \%)$. Artinya, sebagian besar mahasiswa gagal dalam perkuliahan pencak silat dasar. Tujuan penelitian ini adalah untuk melihat Penelitian ini secara umum bertujuan untuk mengetahui perbedaan hasil metode pembelajaran dan kemampuan motorik terhadap keterampilan jurus tunggal Pencak Silat mahasiswa FIK UNP di Padang. Jenis penelitian adalah Komparatif. Metode penelitian yang digunakan adalah eksperimen dengan desain faktorial $2 \times 2$. Sebagai populasi adalah seluruh mahasiswa program studi pendidikan olahraga yang mengambil mata kuliah pencak silat dasar FIK UNP. Teknik pengambilan sampel random sampling sehinggan sampel dalam penelitian ini adalah mahasiswa putera sebanyak 132 mahasiswa. Tes keterampilan jurus tunggal pencak silat menggunakan tes baku jurus tunggal dari IPSI.Tes kemampuan motorik digunakan tes lari $40 \mathrm{~m}$, lempar tangkap bola ke dinding, Shuttle-run, lempar bola medicine,strok stand test, dan kelenturan secara berulang selama 20 detik. Pengujian hipotesis penelitian ini menggunakan teknik analisis varians (ANAVA) dua jalur.Berdasarkan analisis ditemukan Metoda Inkuiri lebih efektif untuk meningkatkan keterampilan Jurus Tunggal Pencak Silat mahasiswa dari pada metoda komando. Terdapat interaksi antara metoda dengan Kemapuan Motorik terhadap peningkatan Jurus Tunggal Pencak Silat mahasiswa. Pada tingkat Kemampuan Motorik tinggi, metoda Inkuiri lebih efektif daripada metoda komando untuk meningkatkan Jurus Tunggal Pencak Silat mahasiswa. Pada tingkat Kemampuan Motorik rendah, metoda Komando lebih efektif dari pada metoda Inkuri untuk meningkatkan keterampilan Jurus Tunggal Pencak Silat mahasiswa.
\end{abstract}

Kata Kunci: Metode,Kemampuan Motorik, Keterampilan Jurus Tunggal Pencak Silat

\section{Abstract}

Looking at the learning outcomes data obtained by FIK UNP students who took basic martial arts courses from 1380 students, as many as 402 people (29.13\%) who did not graduate and delayed scores were $278(20.14 \%)$. That is, most students fail in basic pencak silat lectures. The purpose of this study was to see this study in general aiming to determine the differences in the results of learning methods and motor skills on the skills of a single stance Pencak Silat FIK UNP students in Padang. This type of research is Comparative. The research method used was an experiment with a $2 \times 2$ factorial design. As a population were all students of sports education study programs who took the basic martial arts courses at FIK UNP. The random sampling technique so that the sample in this study were 132 male students. The pencak silat single skill skill test uses the standard single test from IPSI. Tests of motor skills are used for the $40 \mathrm{~m}$ run test, throwing the ball into the wall, Shuttle run, throwing medicine balls, stand test strokes, and repeated flexibility for 20 seconds. Testing the hypothesis of this study uses two-way analysis of variance (ANAVA) techniques. Based on the analysis, it was found that Inquiry Methods were more effective in improving students' skills in the Single Pencak Silat Skill than the command method. There was an interaction between the method with Motorized Skill and the improvement of the student's Single Pencak Silat Skill. At a high level of Motor Capability, Inquiry methods are more effective than the command method for improving student Single Pencak Silat Skills. At a low Motor Capability level, the Command method is more effective than the Inkuri method for improving students' Single Skill Pencak Silat skills

Keywords: Methods, Motor Ability, Single Pencak Silat Skill Skills

\section{Pendahuluan}

Dalam rangka peningkatan kualitas sumber daya manusia Indonesia melalui pembangunan bidang keolahragaan, pemerintah mengupayakan pembinaan dan pengembangan olahraga secara menyeluruh, baik olahraga pendidikan, rekreasi, maupun prestasi.Olahraga pendidikan diselenggarakan sebagai bagian dari proses pendidikan, olahraga rekreasi untuk pemulihan kesehatan, kebugaran jasmani, serta melestarikan budaya daerah dan nasional. Sedangkan olahraga 
prestasi sebagai upaya peningkatan kemampuan atau potensi olahragawan.

Mata kuliah Pencak Silat Dasar salah satu materi perkuliahan yang dimuat dalam perangkat Mata Kuliah Keilmuan dan Keterampilan (MKK). Mata kuliah ini tergolong sebagai mata kuliah wajib dan bersyarat. Wajib dalam artian, semua mahasiswa pada setiap program studi FIK (Pendidikan Olahraga, Pendidikan Kepelatihan, dan Ilmu Keolahragaan) wajib mengambil dan mengikuti pembelajaran Pencak Silat Dasar. Apabila mereka gagal atau belum lulus dalam mata kuliah ini, maka penyelesaian program studinya akan tertunda. Sebagai mata kuliah bersyarat, yaitu mahasiswa dipersyaratkan harus lulus dalam mata kuliah Pencak Silat Dasar untuk dapat mengambil mata kuliah Pencak Silat pendalaman. Artinya, mahasiswa yang belum lulus mata kuliah Pencak Silat Dasar tidak diperbolehkan untuk mengambil mata kuliah Pencak Silat Pendalaman. Hal ini menunjukkan bahwa mata kuliah Pencak Silat Dasar sangat penting dikuasai mahasiswa sebelum melanjutkan ke tingkat pendalaman.

Keberhasilan pembelajaran pencak silat dasar sangat ditentukan oleh faktor, (1) perumusan tujuan; (2) penyusunan materi; (3) penetapan metode dan strategi; dan (4) penyusunan evaluasi. Tujuan pembelajaran harus dirumuskan secara menyeluruh atau mencakup semua materi yang digariskan dalam silabus mata kuliah yang terdiri dari, (a) aspek pengetahuan (cognitive), (b) sikap (affective), (c) gerak (motorik), dan (d) sosio-emosional. Dalam penyusunannya harus sistematis yaitu dari yang sederhana menuju yang lebih kompleks.

Metode adalah cara yang dalam fungsinya digunakan untuk mencapai tujuan.Sanjaya mengatakan, Strategi adalah sebuah perencanaan untuk mencapai sesuatu, sedangkan metode adalah cara yang dapat digunakan untuk melaksanakan strategi. Strategi berfokus pada kiat-kiat atau upaya untuk memperdayakan mahasiswa mau melibatkan diri dalam pembelajaran untuk mencapai tujuan yang ditetapkan. Seperti kiat menghadapi mahasiswa dalam belajar pada waktu, tempat, dan sarana yang kurang menunjang dan sebaliknya. Sementara metoda berkaitan dengan dasar yang akan dipergunakan dalam belajar, seperti metoda bagian dan keseluruhan. Dengan demikian, dalam suatu strategi terkandung berbagai kegiatan untuk mencapai tujuan pembelajaran, sedangkan metode adalah dasar yang dipergunakan dalam strategi.
Berdasarkan studi pendahuluan melalui analisis dokumenter pada FIK UNPselama sembilan semesterterhadap Nilai Semester Mata Kuliah Pencak Silat Dasar Mahasiswa, yaitu dari tahun akademik 2005 - 2009 (Januari - Juni 2005 sampai Januari - Juni 2009). Ditemukan hasil belajar mahasiswa program studi Kepelatihan dari 110 mahasiswa, yang memperoleh nilai $\mathrm{A}$ sebanyak 20 orang $(18,18 \%)$, nilai B sebanyak 10 orang $(9,09 \%)$, nilai D sebanyak 10 orang $(9,09 \%)$, nilai E (tidak lulus) sebanyak 60 orang $(54,54 \%)$, dan Tunda 10 orang $(9,09 \%)$. Hasil belajar program studi Ilmu Keolahragaan dari 259 mahasiswa, memperoleh nilai A sebanyak 30 orang (11,58\%), nilai B sebanyak 82 orang (31,66 \%), nilai C sebanyak 24 orang $(9,26 \%)$, nilai $\mathrm{E}$ (tidak lulus) sebanyak 61 orang $(23,55 \%)$; dan nilai Tunda sebanyak 62 orang $(23,93 \%)$. Hasil belajar program studi Pendidikan Olahraga dari 1011 mahasiswa, yang memperoleh nilai A sebanyak $202(19,98 \%)$, nilai B sebanyak 150 $(14,83 \%)$, niilai C sebanyak 134 orang $(13,25 \%)$, nilai D sebanyak 18 orang $(1,78 \%$ ), nilai E (tidak lulus) sebanyak 281 orang $(27,79 \%)$, dan nilai Tunda sebanyak 226 orang $(22,35 \%)$.

Mencermati data hasil belajar atau nilai yang diperoleh mahasiswa di atas, menunjukkan bahwa semua mahasiswa yang mengambil mata kuliah pencak silat dasar dari sebanyak 1380 mahasiswa FIK UNP selama Sembilan semester tersebut, terdapat sebanyak 402 orang $(29,13 \%)$ yang tidak lulus dan nilai tunda sebanyak 278 $(20,14 \%)$. Artinya, sebagian besar mahasiswa gagal dalam perkuliahan pencak silat dasar.

Kecenderungan rendahnya hasil belajar atau masih banyaknya jumlah mahasiswa yang tidak lulus atau gagal, hal ini menurut Buchari Alma dikarenakan dosennya tidak produktif. Dalam pandangan baru menghendaki agar tingkat produktivitas dipertinggi dengan menekan tingkat ketidak lulusan/kegagalan mahasiswa seminimal mungkin dengan cara memperbaiki metode pembelajaran, evaluasi, dan sebagainya.Seiring dengan itu, Soedijarto mengemukakan bahwa bila terjadi penurunan mutu pendidikan, maka yang pertama kali harus diamati adalah kualitas proses belajar mengajar yang terjadi di kelas. Dalam konteks pembelajaran pencak silat dasar, terjadinya penurunan mutu pendidikan (rendahnya nilai yang dapat dicapai), maka yang harus dikaji terlebih dahulu adalah kualitas pembelajaran mata kuliah Pencak Silat Dasar itu sendiri, dan selanjutnya dilakukan pengamatan 
terhadap berbagai komponen penentu keberhasilan pembelajaran.

Dilihat dari sudut pengajar atau dosen, diperoleh kesan bahwa rendahnya hasil belajar pencak silat mahasiswa FIK UNP tersebut di atas, lebih mengarah pada penggunaan metode pembelajaran yang kurang tepat.Dosen terkesan belum menggunakan metode pembelajaran yang bervariasi. Maksudnya, masih ditemukan dosen menggunakan metode pembelajaran secara konvensional, pada hal setiap metode pembelajaran mempunyai keunggulan dan kelemahan satu sama lainnya. Memang tidak ada satupun metode pembelajaran dianggap ampuh untuk segala situasi.

Dalam pembelajaran pencak silat dasar, dosen sering ditemui terlalu banyak komentar atau ceramah dan program belajar tidak sistematis, sehingga penggunaan waktu belajar aktif (active learning time) tidak efektif dan effisien.Kurang memberikan kesempatan kepada mahasiswa untuk menemukan sendiri gerakan-gerakan dalam keterampilan dasar pencak silat pada saat mereka melakukan latihan secara berpasangan, sangat minimnya koreksi-koreksi gerakan yang seharusnya, pada hal bimbingan dari dosen sangat mereka harapkan.Implikasinya, tujuan pembelajaran yang telah digariskan kurang tercapai.

Koreksi gerakan adalah penyampaian informasi oleh dosen tentang kesalahan-kesalahan yang dilakukan mahasiswa. Menurut Yanuar Kiram, penyampaian informasi tentang kesalahan itu meliputi: (a) bentuk kesalahan yang terjadi, (b) berat-ringannya kesalahan, (c) sumber penyebab kesalahan, dan (d) akibat dari kesalahan yang akan terjadi. Selanjutnya dikatakan bahwa koreksi gerakan dalam proses pembelajaran keterampilan jurus tunggal sangat vital dan strategis. Pengertian vital diterjemahkan sebagai aspek yang sangat menentukan keberhasilan proses pembelajaran. Tanpa koreksi gerakan, seseorang tidak akan pernah mencapai hasil belajar yang optimal. Oleh karena kurangnya koreksi gerakan, mahasiswa akanmengalami kesulitan untuk menemukan gerakan atau keterampilan jurus tunggal pencak silat bagaimana yang seharusnya mereka lakukan.

Selanjutnya juga terlihat dalam cara mengajarkan bagian-bagian gerak jurus tunggal pencak silat yang tidak secara sistematis, sehingga mahasiwa menemukan kesulitan dalam mengukuti teknik-teknik gerakan secara baik. Seiring dengan itu, pembelajaran terkesan kurang demokratis, dan bahkan dosen cenderung mengembangkan prinsip bahwa distribusi sebuah keputusan harus dilakukan secara hirarkis, dari atas ke bawah atau dari dosen kepada mahasiswa. Penerapan pembelajaran dilakukan dengan gaya perintah dari dosen, mahasiswa kurang berkesempatan dalam pembahasan atau umpan balik feed back. Pembelajaran sering mematikan kreativitas mahasiswa, kurang menghargai dan kurang peduli terhadap keragaman mahasiswa.

Seterusnya diarahkan pada berbagai penentu keberhasilan pembelajaran dari aspek aktivitas belajar atau mahasiswa.Dalam kegiatan ini, diperoleh fenomena yang diduga berpengaruh terhadap pembelajaran, yaitu faktor keragaman mahasiswa.Keragaman dimaksud berkenaan dengan kemampuan motorik mahasiswa tersebut.Menurut Burton kemampuan motorik adalah kemampuan individual yang mendasari penampilan dalam berbagai keterampilan olahraga. Kemampuan motorik seseorang dapat ditinjau atas dua aspek, yaitu (a) kemampuan gerak perseptual (perceptual motor ability), dan (b) kemampuan ketangkasan fisik (physical proficiency abilities). Dengan kata lain, antara masing-masing mahasiswa yang mengambil mata kuliah pencak silat dasar terdapat perbedaan individual dalam kemampuan motorik yang berkenaan dengan ketangkasan fisik mereka.

Fenomena yang cukup menarik diamati sehubungan dengan kemampuan motorik tersebut, dosen terkesan dalam aktivitas pembelajaran memperlakukan mahasiswa sama atau tanpa melihat perbedaan atau keragaman individual secara selektif. Sehingga hal ini membuat tingkat keberhasilan mahasiswa dalam belajar terlalu jauh, antara mahasiswa yang memiliki kemampuan motorik tinggi dengan yang berkemampuan motorik rendah. Artinya, dosen belum mengelompokkan mahasiswa berdasarkan perbedaan kemampuan motorik mereka.

Kedua variabel utama yang diduga berpengaruh terhadap hasil belajar keterampilan jurus tunggal pencak silat, yaitu: metode pembelajaran dan kemampuan motorik perlu mendapatkan perhatian dan ditelusuri dengan mengadakan studi eksperimen. Jika tidak dikhawatirkan hasil pembelajaran pencak silat dasar akan selalu rendah. Dalam artian, tidak akan berubah kearah lebih baik. Secara khusus pada penelitian ini juga akan dilihat perbedaan pengaruh metode pembelajaran inkuiri dan komando dengan kemampuan motorik tinggi dan rendah terhadap keterampilan jurus tunggal pencak silat. 
Penelitian ini penting dilaksanakan untuk memberikan jawaban terhadap permasalahan rendahnya hasil belajar keterampilan jurus tunggal pencak silat yang diduga dikarenakan pengaruh metode pembelajaran dan kemampuan motorik.Seiring dengan itu, sekaligus sebagai upaya untuk menciptakan paradigma baru dalam pembelajaran Pencak Silat Dasar.Hal ini bertujuan agar hasil pembelajaran pencak silat yang diprogramkan menjadi lebih baik. Pencak silat adalah seni beladiri produk budaya lokal dalam rangka budaya masyarakat rumpun Melayu. Dalam kaitan dengan nama Pencak dan silat, ada pihak yang menyamakan pengertian pencak dengan silat dan ada pihak yang membedakannya. Namun demikian, para tokoh pendiri IPSI akhirnya tidak membedakan pengertian pencak dengan silat, karena kedua kata tersebut memang mempunyai pengertian yang sama. Kata pencak maupun silat sama mengandung pengertian kerohanian, irama, keidahan dan kiat maupun praktek kinerja atu aplikasinya. Dalam rangka usaha untuk mempersatukan pencak dan silat, maka pada tahun 1948 kedua kata tersebut telah dipadukan menjadi pencak silat. Ciri khusus lainnya pada pencak silat adalah menggambarka budaya dari kesenian daerah, seperti tabuh, gendang, rebana, seruling, gong, dan alat musik lainnya. Pada jalur kesenian terdapat kaidahkaidah gerak dari irama yang merupakan suatu pendalaman khusus. Gerakan-gerakan yang terdapat dalam pencak silat pada saat ini sering ditampilkan dalam berbagai acara perkawinan, upacara adat atau lain sebagainya. Tujuan penampilan gerakan pencak silat tersebut sebagai hiburan bagi para undangan/penonton yang hadir pada suatu perhelatan/upacara adat tersebut. jurus tunggal merupakan hal yang pokok di samping kategori lainnya. Jurus tunggal merupakan salah satu kategori seni pencak silat yang dipertandingkan. Jurus tunggal merupakan suatu bentuk keterampilan yang kompleks yang terdiri dari berbagai macam gerak dan jurus, baik tangan kosong maupun senjata. Dalam buku peraturan disebutkan bahwa kategori tunggal adalah pertandingan pencak silat yang menampilkan seorang pesilat memperagakan kemahirannya dalam jurus baku tunggal secara benar, tepat dan mantap penuh penjiwaan dengan tangan kosong dan bersenjata.

Jurus tunggal ada 14 jurus, terdiri dari 7 jurus tangan kosong, 3 jurus senjata golok, dan 4 jurus senjata tongkat. Untuk semua gerakkan jurus tunggal ini terdiri dari 100 gerakan. Lama waktu penampilan jurus tunggal saat bertanding ditetapkan selama 3 menit. Perhitungan waktu dimulai dari gong pertama dibunyikan sampai dengan tanda berbunyinya gong terakhir. Selama 3 menit tersebut pesilat melakukan serangkaian gerakan sesuai dengan ketentuannya. Sedangkan untuk penilaian jurus tunggal, Lubis memaparkan bahwa penilaian dalam pencak silat terdiri atas nilai kebenaran dan kemantapan. Kemampuan motorik adalah kemampuan seseorang dalam melakukan sebuah gerakan motor ability yang baik dapat dikuasai oleh seseorang, melalui suatu program latihan. Apabila seseorang dilatih dengan teknik yang benar dia akan memiliki simpanan motorik baik dan benar. Pate mengemukankan bahwa keterampilan diartikan satu aktivitas atau tugas motorik yang merupakan indikator dari suatu tingkat kemahiran. Richard A. Magil kinerja keterampilan motorik dipengaruhi oleh (1) keterampilan motorik, (2) lingkungan kinerja dan (3) Karakteristik fisik dan kognitif mengenai kineja kerterampilan seseorang. Menurut Rusli Lutan penguasaan keterampilan motorik tidak terjadi secara otomatif atau tiba-tiba mendadak, tetapi merupakan akumulasi dari pengalaman dan dipengaruhi proses kematangan. Selanjutnya Hockey menggambarkan komponen-komponen kemampuan motorik terdiri dari enam komponen, yaitu kelincahan, tenaga, kordinasi, kecepatan, waktu reaksi dan keseinbangan. Flesman dalam Singer mengemukakan sembilan kemampuan motorik yaitu kekuatan statis, daya ledak kekuatan tubuh, kelentur statis, kelenturan dinamis, kordinasi tubuh kasar kordinasi berbagai bagian tubuh, dan stamina.

Berdasarkan pendapat di atas, dapat disimpulkan bahwa kemampuan motorik adalah suatu kemampuan yang dimiliki seseorang secara melekat yang mengacu pada gerakan fisik. Fungsi utama dari kemampuan motorik adalah menghubungkan kesanggupan dan kemapuan setiap individu yang berguna untuk mempertinggi daya kerjanya. Maksudnya, makin tinggi kemampuan seseorang maka dimungkinkan daya kerjanya akan menjadi makin tinggi dan begitu juga sebaliknya. Kemampuan motorik merupakan kualitas kemampuan seseorang yang dapat mempermudah dalam melakukan keterampilan gerak. Kemampuan motorik dapat dipandang sebagai landasan keberhasilan masa datang di dalam melakukan tugas keterampilan gerak. Seseorang yang memiliki kemampuan motorik lebih tinggi cenderung akan lebih berhasil dalam 
menyelesaikan tugas-tugas keterampilan gerak. Istilah metode seringkali disamakan artinya dengan strategi atau teknik. Secara sempit memang identik dengan strategi atau teknik, yaitu cara penyampaian isi pesan kepada mahasiswa untuk mencapai tujuan yang telah ditetapkan. Secara luas, dapat mencakup antara lain rencana pembelajaran, pendekatan, pemilihan sumbersumber termasuk media, pengelompokkan mahasiswa dan pengukuran keberhasilannya. Carl Gabbard juga mengatakan bahwa metode pembelajaran mengacu pada suatu proses manipulasi lingkungan, masing-masing metode adalah gabungan dari beberapa kemungkinan variable.

Sudjana mengatakan sebagai penetapan semua aspek yang berkaitan dengan pencapaian tujuan pembelajaran termasuknya di dalamnya perencanaan, pelaksanaan dan peniliaian terhadap proses, hasil, dan pengaruh kegiatan pembelajaran. Merril mengatakan dapat berupa pendekatan Dosen dalam menggunakan informasi atau pola umum perbuatan Dosen/mahasiswa dalam mewujudkan kegiatan belajar atau macam dan urutan perbuatan belajar mengajar atau suatu susunan komponen-komponen pembelajaran untuk mencapai hasil belajar materi tertentu. atau keseluruhan pendekatan pembelajaran yang dikombinasikan menjadi suatu kesatuan dalam suatu sistem yang mencakup dalam bentuk kerjasama sistem, format, stimulus, respon umpan balik generalitas, contoh-contoh, organisasi, penyampain, urutan materi, ruang lingkup, ukuran dan kecepatan yang digunakan dalam pembelajaran. Setiap metode pembelajaran akan menciptakan suatu bentuk pembelajaran dengan kondisi tertentu yang bertujuan untuk membantu proses pembelajaran yang ditandai oleh tercapainya tujuan pembelajaran secara efektif dan efisien. Metode pembelajaran inquiry "merupakan kegiatan pembelajaran yang melibatkan secara maksimal seluruh keterampilan mahasiswa untuk mencari dan menyelidiki sesuatu (benda, manusia, atau peristiwa) secara sistematis, kritis, logis, analitis sehingga mereka dapat merumuskan sendiri penemuannya dengan penuh percaya diri”. Metode inquiry merupakan pendekatan mengajar yang berusaha meletakkan dasar dan pengembangan cara berfikir ilmiah, pendekatan ini menempatkan mahasiswa lebih banyak belajar sendiri, mengembangkan kekreatifan dalam memecahkan masalah. Metode mengajar inkuiri adalah suatu teknik mengajar gerak yang membantu mahasiswa untuk mempertinggi pengetahuan pada tubuh dan potensinya untuk bergerak dalam ruang. Mahasiswa didorong untuk menjelajahi dan meneliti dalam setiap klasifikasi gerak jurus tunggal dalam pencak silat dasar. Metode ini cukup sesuai digunakan untuk penguasaan Keterampilan jurus tunggal pada hirarkhi pertama disebut dengan metode penjelajahan. Komando adalah suatu metode pendekatan ditandai oleh dosen membuat semua keputusan di dalam anatomi dari metode pembelajaran. Dosen yang membuat keputusan tentang bentuk, tempo, urutan, intensitas, penilaian dan penetapan tujuan untuk setiap tahap pembelajaran, sedangkan mahasiswa merespon semua keputusan Dosen tersebut. Sehingga dapat dikatakan bahwa semua keputusan Dosen sama dengan keputusan mahasiswa. Dalam metode mengajar komando atau perintah, semua keputusan diambil oleh dosen. Peran dosen adalah membuat semua keputusan sebelum, sedang dan sesudah di dalam pembelajaran. Sedangkan peran mahasiswa sebaliknya, yaitu melaksanakan, mengikuti, dan mematuhi perintah dosen. Intisari dari metode komando adalah langsung dan berhubungan segera antara stimulus Dosen dan tanggapan mahasiswa . Stimulus (isyarat komando) oleh Dosen mendahului setiap bergeraknya mahasiswa yang melaksanak an menurut model yang diperkenalkan oleh Dosen. Karenanya, semua keputusan tentang lokasi, perawakan, permulaan waktu, langkah dan irama, tempat berhenti waktu, jangka waktu, dan interval dibuat oleh Dosen. Berdasarkan telaahan teori-teori di atas, maka yang dimaksud dengan metode mengajar komando dalam penelitian ini adalah suatu metode mengajar yang dalam perlakuannya memberikan komando pada mahasiswa untuk melakukan aktivitas tugas-tugas keterampilan jurus tunggal pencak silat yang diberikan dosen di FIK UNP. Mahasiswa diberikan serangkain kegiatan Keterampilan yang telah diprogram sebelumnya. Metode mengajar ini lebih cenderung dalam bentuk rangkain latihan sesuai dengan tujuan yang akan dicapai, yaitu mengembangkan sekaligus membentuk Keterampilan jurus tunggal pencak silat yang sesuai dengan kondisi mahasiswa.

\section{Metode Penelitian}

Jenis penelitian ini adalah penelitian komparatif. Metode penelitian yang digunakan adalah metode penelitian eksperimen dengan desain faktorial 2 x 2, Penelitian ini dilaksanakan 
pada Mahasiswa FIK UNP diKota Padang. Sebagai populasi target dalam penelitian ini adalah seluruh mahasiswa program studi pendidikan olahraga yang mengambil mata kuliah pencak silat dasar pada FIK UNP, terdaftar pada semester genap (Januari - Juni) tahun akademik 2012/ 2013, terdiri dari 4 seksi yaitu sebanyak 170 mahasiswa.

Memprhatikan begitu banyaknya mahasiswa yang mengambil mata kuliah pencak silat dasar dimaksud, serta mengingat keterbatasan peneliti, maka perlu ditetapkan populasi terjangkau (accessible population) secara random sampling. Karena semua anggota populasi telah memiliki karkteristik yang sama (homogen), yaitu sama-sama mempergunakan program atau silabus, tenaga pengajar, bahan ajar, dan sarana prasarana serta kurikulum yang sama. Dengan demikian, sebagai populasi terjangkaunya akan diambil mahasiswa putera saja, yaitu sebanyak 132 mahasiswa, sekaligus dijadikan sebagai anggota sampel. Tes keterampilan jurus tunggal pencak silat menggunakan tes baku jurus tunggal dari IPSI yang disesuaikan dengan kebutuhan pembelajaran pencak silat, yaitu keterampilan jurus tunggal pencak silat yang berkaitan dengan mata kuliah di FIK UNP. Untuk mendapatkan data kemampuan motorik digunakan tes.Kecepatan dengan tes lari $40 \mathrm{~m}$, koordinasi dengan teslempar tangkap bola ke dinding, kelincahan dengan tes Shuttle-run, Explosive Power dengan tes Lempar bola medicine, Keseimbangan dengan tes strok stand test, dan kelentukan dengan tes kelenturan posisi badan sambil berdiri di dinding dan menjangkaukan kedua tangan arah belakang kepala dan lantai ke kiri/kanan secara berulang selama 20 detikAnalisis data Pengujian hipotesis penelitian ini menggunakan teknik analisis varians (ANAVA) dua jalur dengan rancangan faktorial 2x2.Dengan taraf kepercayaan $\alpha=0,05$. Apabila pengujian hipotesis signifikan dan berinteraksi pada jumlah $\mathrm{n}$,maka dilanjutkan dengan uji Tukey untuk melihat efek interaksi yang lebih baik

\section{Hasil Penelitian dan Diskusi}

1. Hasil Keterampilan jurus tunggal pencak silat yang Diberi Metode Pembelajan Inkuiri (Kelompok $\mathbf{A}_{1}$ )

Data hasil pengukuran Sampel dalam kelompok ini yang terdiri dari 36 Sampel, skor tertinggi 87.67, skor terendah 66.00, dan jarak pengukuran (range) 21.67. Rerata skor 76.54, simpangan baku 6.91, median 76.33 ,modus 69.33. Distribusi frekuensi metode latihan Sampel kelompok ini dengan banyak kelas 6, panjang kelas 3.611, dapat digambarkan dalam tabel 11 distribusi frekuensi berikut:

Distribusi Frekuensi Keterampilan jurus tunggal pencak silat yang Diberi Metode Pembelajaran Inkuiri (Kelompok $A_{1}$ )

\begin{tabular}{|c|c|c|c|c|}
\hline $\mathrm{N}$ & \multicolumn{2}{|}{ KELAS INTERVAL } & FREKUENSI \\
\cline { 3 - 5 } $\mathrm{O}$ & \multicolumn{2}{|c|}{} & $\mathrm{F}$ & $\%$ \\
\hline 1 & 65.995 & 69.614 & 7 & 19.44 \\
\hline 2 & 69.615 & 73.234 & 9 & 25.00 \\
\hline 3 & 73.235 & 76.854 & 0 & 0.00 \\
\hline 4 & 76.855 & 80.474 & 3 & 8.33 \\
\hline 5 & 80.475 & 84.094 & 10 & 27.78 \\
\hline 6 & 84.095 & 87.714 & 7 & 19.44 \\
\hline \multicolumn{3}{|c|}{ JUMLAH } & 36 & 100.00 \\
\hline
\end{tabular}

Tabel di atas, menunjukkan bahwa terdapat sebanyak 7 orang (19.44\%) berada pada kelompok $65.995-69.614$, 9 orang $(25.00 \%)$ berada pada kelompok 69.615-73.234, 0 orang $(0.00 \%)$ pada kelompok $73.235-76.854,3$ orang (8.33\%) pada kelompok $76.855 \quad-80.474,10$ orang $(27,78 \%)$ berada pada kelompok $80.475-$ 84.094 , dan 7 orang (19.44\%) pada kelompok 84.095-87.714. Untuk lebih jelasnya, penjabaran distribusi frekuensi di atas dapat dilihat pada histogram berikut:

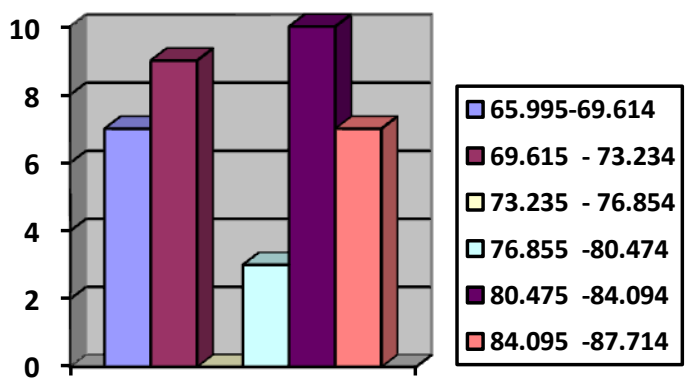

Histogram Keterampilan Jurus Tunggal Pencak Silat diberi Metode Pembelajaran Inkuiri (A1).

\section{Hasil Keterampilan Jurus Tunggal Pencak Silat Diberi Metode Pembelajaran Komando $\left(\mathbf{A}_{2}\right)$}

Data hasil pengukuran ,keterampilan Jurus tunggal pencak silat Sampel dalam kelompok ini yang terdiri dari 36 Sampel, skor tertinggi 80.67 skor terendah 67.67, dan jarak 
pengukuran (range) 13. Rerata skor 75.14, simpangan baku 2.83, median 75.83, modus 76.00. Distribusi frekuensi Sampel kelompok ini dengan banyak kelas 6 , dan panjang kelas 2.167 , dapat digambarkan dalam tabel 6 distribusi frekuensi berikut:

Distribusi Frekuensi Keterampilan Jurus tunggal pencak silat Diberi Metode Pembelajaran Komando $\left(\mathrm{A}_{2}\right)$

\begin{tabular}{|c|c|c|c|c|}
\hline $\mathrm{N}$ & \multicolumn{2}{|c|}{ KELAS INTERVAL } & \multicolumn{2}{c|}{ FREKUENSI } \\
\cline { 4 - 5 } $\mathrm{O}$ & \multicolumn{2}{|c|}{} & $\mathrm{F}$ & $\%$ \\
\hline 1 & 67.665 & 69.834 & 1 & 2.78 \\
\hline 2 & 69.835 & 72.004 & 4 & 11.11 \\
\hline 3 & 72.005 & 74.174 & 9 & 25.00 \\
\hline 4 & 74.175 & 76.344 & 13 & 36.11 \\
\hline 5 & 76.345 & 78.514 & 4 & 11.11 \\
\hline 6 & 78.515 & 80.684 & 5 & 13.89 \\
\hline \multicolumn{3}{|c|}{ JUMLAH } & 36 & 100.00 \\
\hline
\end{tabular}

Tabel di atas, menunjukkan bahwa terdapat sebanyak 1 orang $(2.78 \%)$ berada pada kelompok 67.665-69.834, 4 orang $(11.11 \%)$ berada pada kelompok 69.835-72.004, 9 orang (25.00\%) pada $72.005-74.174,13$ orang $(36.11 \%)$ pada 74.175 76.344 , 4 orang $(11.11 \%)$ pada kelompok 76.345 78.514 , dan 5 orang (13.89\%) pada kelompok 78.515-80.684. Untuk lebih jelasnya, penjabaran distribusi frekuensi di atas dapat dilihat pada histogram berikut.

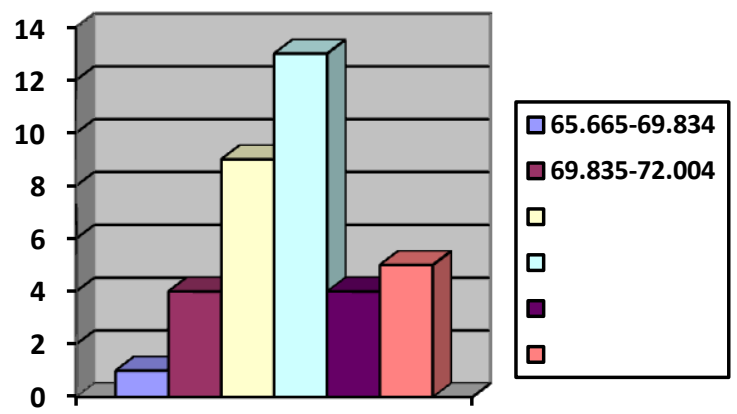

Histogram Keterampilan Jurus Tunggal Pencak Silat Diberi Metode Pembelajaran Komando ( $\left.\mathbf{A}_{2}\right)$

\section{Hasil Keterampilan Jurus Tunggal Pencak Silat Kelompok yang Memiliki Kemampuan Motorik Tinggi $\left(B_{1}\right)$}

Data hasil pengukuran Sampel dalam kelompok ini yang terdiri dari 36 Sampel $(\mathrm{n}=36)$ dengan skor tertinggi 87.67 skor terendah 71.00 , dan jarak pengukuran (range) 16.67. Rerata skor 78.56, simpangan baku 4.96, median 77.66, modus 76.00. Distribusi frekuensi Sampel kelompok ini dengan banyak kelas 6 dan panjang kelas 2.778 dapat digambarkan dalam tabel 7 distribusi frekuensi berikut:

Distribusi Frekuensi Keterampilan jurus tunggal pencak silat Memiliki Kemampuan motorik Tinggi $\left(B_{1}\right)$

\begin{tabular}{|c|c|c|c|c|}
\hline \multirow{2}{*}{ NO } & \multirow{2}{*}{\multicolumn{2}{|c|}{ KELAS INTERVAL }} & \multicolumn{2}{|c|}{ FREKUENSI } \\
\hline & & & $\mathrm{F}$ & $\%$ \\
\hline 1 & 70.995 & 73.774 & 6 & 16.67 \\
\hline 2 & 73.775 & 76.554 & 12 & 33.33 \\
\hline 3 & 76.555 & 79.334 & 1 & 2.78 \\
\hline 4 & 79.335 & 82.114 & 8 & 22.22 \\
\hline 5 & 82.115 & 84.894 & 5 & 13.89 \\
\hline 6 & 84.895 & 87.674 & 4 & 11.11 \\
\hline & JUMLA & & 36 & 100.00 \\
\hline
\end{tabular}

Tabel di atas, menunjukkan bahwa terdapat sebanyak 6 orang $(16.67 \%)$ berada pada kelompok 70.995-73.774, 12 orang (33.33\%) berada pada kelompok $73.775-76.554,1$ orang (2.78\%) pada kelompok 76.555-79.334, 8 orang (22.22\%) berada pada kelompok 79.335-82.114, 5 orang $(13.89 \%)$ berakda pada kelompok 82.11584.894 , dan 4 orang $(11.11 \%)$ berada pada kelompok 84.895-87.674. Untuk lebih jelasnya, penjabaran distribusi frekuensi di atas dapat dilihat pada histogram berikut:

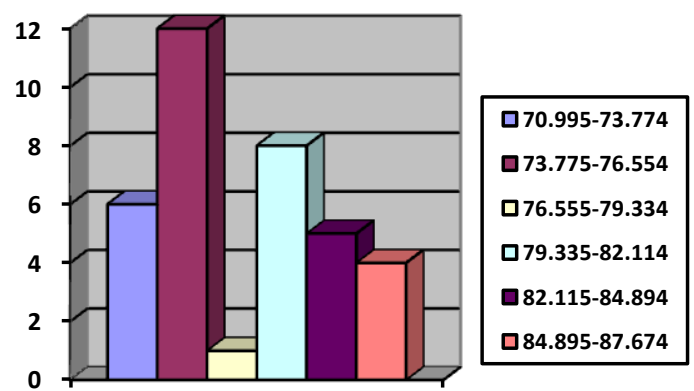

Histogram Keterampilan Jurus Tunggal Pencak Silat Kelompok yang Memiliki Kemampuan motorik Tinggi $\left(B_{1}\right)$

\section{Hasil Keterampilan Jurus Tunggal Pencak Silat Kelompok yang Memiliki Kemampuan motorik Rendah $\left(B_{2}\right)$}

Data hasil pengukuran Sampel dalam kelompok ini yang terdiri dari 36 Sampel $(n=36)$ dengan skor tertinggi 80.67 skor terendah 66.00, dan jarak pengukuran (range) 14.67. Rerata skor 73.08, simpangan baku 4,05, median 72.16 dan modus 69.33. Distribusi frekuensi Sampel kelompok dengan banyak kelas 6 dan pnjang 
kelas 2.445 dapat digambarkan dalam tabel 8 distribusi frekuensi berikut:

Distribusi Frekuensi Keterampilan Jurus Tunggal Pencak Silat yang Memiliki Kemampuan motorik Rendah $\left(\mathbf{B}_{2}\right)$

\begin{tabular}{|c|c|c|c|c|}
\hline \multirow{2}{*}{$\begin{array}{c}\mathrm{N} \\
\mathrm{o}\end{array}$} & \multicolumn{2}{|c|}{ Kelas interval } & \multicolumn{2}{c|}{ Frekuensi } \\
\cline { 4 - 5 } & & $\mathrm{F}$ & $\%$ \\
\hline 1 & 65.995 & 68.444 & 4 & 11.11 \\
\hline 2 & 68.445 & 70.894 & 7 & 19.44 \\
\hline 3 & 70.895 & 73.344 & 11 & 30.56 \\
\hline 4 & 73.345 & 75.794 & 3 & 8.33 \\
\hline 5 & 75.795 & 78.244 & 6 & 16.67 \\
\hline 6 & 78.245 & 80.694 & 5 & 13.89 \\
\hline \multicolumn{3}{|c|}{ Jumlah } & 36 & 100.00 \\
\hline
\end{tabular}

Tabel di atas, menunjukkan bahwa terdapat sebanyak 4 orang $(11.11 \%)$ berada pada kelompok 65.995-68.444, 7 orang (19.44\%) berada pada kelompok 68.445-70.894, 11 orang (30.56\%) pada kelompok 70.895-73.344, 3 orang (8.33\%) pada kelompok 73.345-75.794, 6 orang (16.67\%) berada pada kelompok 75.795-78.244, Dan 5 orang (13.89\%) berada pada kelompok 78.245-80.694. Untuk lebih jelasnya, penjabaran distribusi frekuensi di atas dapat dilihat pada histogram berikut:

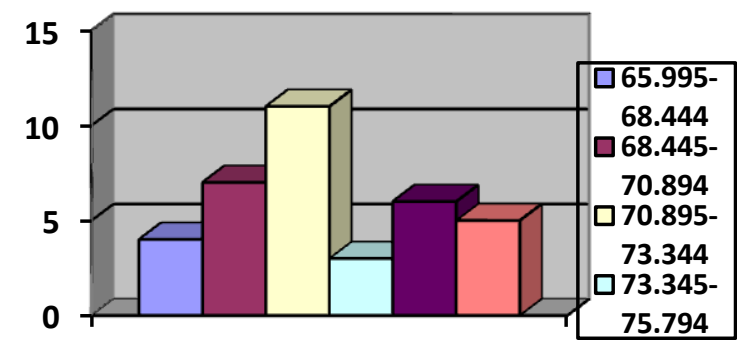

Histogram Keterampilan Jurus Tunggal Pencak Silat Kelompok yang Memiliki Kemampuan motorik Rendah $\left(\mathbf{B}_{2}\right)$.

\section{Hasil Keterampilan Jurus Tunggal Pencak} Silat yang diajar Motode Pembelajaran Inkuiri pada Kemampuan motorik Tinggi $\left(\mathbf{A}_{1} \mathbf{B}_{1}\right)$

Data hasil pengukuran Keterampilan Jurus Tunggal Pencak Silat Sampel dalam kelompok ini terdiri dari 18 Sampel $(\mathrm{n}=18)$ dengan skor tertinggi 87.67, skor terendah 79.00, dan jarak pengukuran (range) 8.67. Rerata skor 83.00 , simpangan baku 2.44, median 82.33 dan modus 81.33. Distribusi frekuensi Sampel kelompok dengan banyak kelas 5 dan panjang kelas 1.733 dapat digambarkan dalam tabel 9 distribusi frekuensi berikut:

Distribusi Frekuensi Keterampilan Jurus

Tunggal Pencak Silat diberi Metode

Pembelajaran Inkuiri pada Kemampuan motorik Tinggi $\left(A_{1} B_{1}\right)$

\begin{tabular}{|c|c|c|c|c|}
\hline \multirow{2}{*}{ No } & \multicolumn{2}{|c|}{ Kelas Interval } & \multicolumn{2}{c|}{ Frekuensi } \\
\cline { 3 - 5 } & 78.995 & $\begin{array}{c}80.73 \\
4\end{array}$ & 2 & 11.11 \\
\hline 1 & 80.735 & $\begin{array}{c}82.47 \\
4\end{array}$ & 6 & 33.33 \\
\hline 2 & 82.475 & $\begin{array}{c}84.21 \\
4\end{array}$ & 2 & 11.11 \\
\hline 3 & 84.215 & $\begin{array}{c}85.95 \\
4\end{array}$ & 5 & 27.78 \\
\hline 4 & 85.955 & $\begin{array}{c}87.69 \\
4\end{array}$ & 3 & 16.67 \\
\hline 5 & Jumlah & & 18 & 100.00 \\
\hline \multicolumn{5}{|c|}{}
\end{tabular}

Tabel di atas, menunjukkan bahwa terdapat sebanyak 2 orang (11.11\%) berada pada kelompok 78.995-80.734, 6 orang (33.33\%) pada kelompok $80.735-82.474,2$ orang (11.11\%) berada pada kelompok 82.475-84.214, 5 orang $(27,78 \%)$ berada pada kelompok 84.21585.954dan 3 orang $(16,67 \%)$ berada pada kelompok 85.955-87.694. Untuk lebih jelasnya, penjabaran distribusi frekuensi di atas dapat dilihat pada histogram berikut:

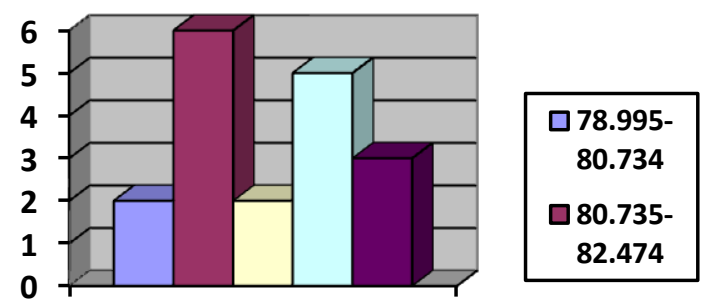

Histogram Keterampilan Jurus Tunggal Pencak Silat diberi Metode Pembelajaran Inkuiri pada Kelompok Kemampuan motorik Tinggi $\left(A_{1} B_{1}\right)$

6. Hasil Keterampilan Jurus Tunggal Pencak Silat Diberikan Metode Pembelajaran Inkuiri pada Kategori Kemampuan motorik Rendah $\left(A_{1} B_{2}\right)$

Data hasil pengukuran Keterampilan Jurus Tunggal Pencak Silat pada Sampel dalam 
kelompok ini terdiri dari 18 Sampel $(\mathrm{n}=18)$ dengan skor tertinggi 72.67, skor terendah 66.00, dan jarak pengukuran (range) 6.67. Rerata skor 70.14, simpangan baku 1.88, median 70.33 dan modus 69.33. Distribusi frekuensi Sampel kelompok dengan banyak kelas 5 dan panjang kelas 1.33 dapat digambarkan dalam tabel 10 distribusi frekuensi berikut:

\section{Distribusi Frekuensi Keterampilan Jurus Tunggal Pencak Silat Diberi Metode Pembelajaran Inkuiri pada Kategori Kemampuan motorik Rendah $\left(\mathbf{A}_{1} \mathbf{B}_{2}\right)$}

\begin{tabular}{|c|c|c|c|c|}
\hline \multirow{2}{*}{ No. } & \multicolumn{2}{|c|}{ Kelas Interval } & \multicolumn{2}{c|}{ Frekuensi } \\
\cline { 4 - 5 } & & & $\mathrm{F}$ & $\%$ \\
\hline 1 & 65.995 & 67.334 & 5 & 27.78 \\
\hline 2 & 67.335 & 68.674 & 4 & 22.22 \\
\hline 3 & 68.675 & 70.014 & 1 & 5.56 \\
\hline 4 & 70.015 & 71.344 & 5 & 27.78 \\
\hline 5 & 71.345 & 72.674 & 3 & 16.67 \\
\hline \multicolumn{3}{|c|}{ Jumlah } & 18 & 100.00 \\
\hline
\end{tabular}

Tabel di atas, menunjukkan bahwa terdapat sebanyak 5 orang $(27,78 \%)$ berada pada kelompok 65.995-67.334, 4 orang $(22,22 \%)$ berada pada kelompok 67.335-68.674, 1 orang (5,56\%) pada kelompok 68.675-70.014, dan 5 orang $(27,78 \%)$ pada kelompok 70.015-71.344, dan 3 orang $(16,67 \%)$ berada pada kelompok 71.345-72.674. Untuk lebih jelasnya, penjabaran distribusi frekuensi di atas dapat dilihat pada histogram berikut:
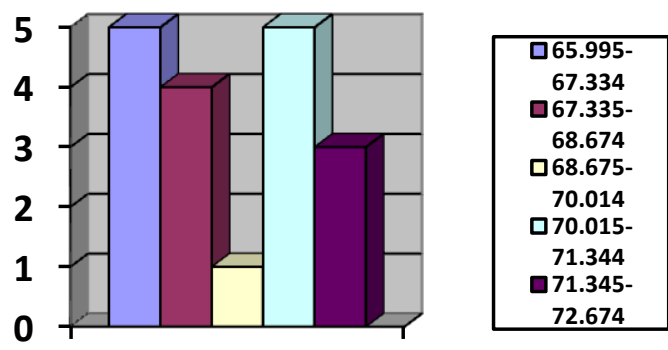

Histogram Keterampilan Jurus Tunggal Pencak Silat Diberi Metode Pembelajaran Inkuiri pada Kategori Kemampuan motorik Rendah $\left(\mathbf{A}_{1} \mathbf{B}_{2}\right)$

7. Hasil Keterampilan Jurus Tunggal Pencak Silat Kelompok Diberi Metode Pembelajaran Komando pada Kategori Kemampuan motorik Tinggi $\left(\mathbf{A}_{2} \mathbf{B}_{1}\right)$
Data hasil pengukuran Keterampilan Jurus Tunggal Pencak Silat pada Sampel dalam kelompok ini terdiri dari 18 Sampel $(\mathrm{n}=18)$ dengan skor tertinggi 76.33, skor terendah 71.00, dan jarak pengukuran (range) 5.33. Rerata skor 74,27 , simpangan baku 1.69, median 74.16 dan modus 76.00. Distribusi frekuensi Sampel kelompok dengan banyak kelas 5 dengan panjang kelas 1.006 dapat digambarkan dalam tabel distribusi frekuensi berikut.

Distribusi Frekuensi Keterampilan Jurus

Tunggal Pencak Silat Diberi Metode

Pembelajaran Komando pada Kategori

Kemampuan motorik Tinggi $\left(\mathbf{A}_{2} \mathbf{B}_{1}\right)$

\begin{tabular}{|c|c|c|c|c|}
\hline \multirow{2}{*}{ No } & \multicolumn{2}{|c|}{ Kelas interval } & \multicolumn{2}{c|}{ Frekuensi } \\
\cline { 4 - 5 } & & & $\mathrm{F}$ & $\%$ \\
\hline 1 & 70.995 & 72.064 & 3 & 16.67 \\
\hline 2 & 72.065 & 73.134 & 1 & 5.56 \\
\hline 3 & 73.135 & 74.204 & 5 & 27.78 \\
\hline 4 & 74.205 & 75.274 & 2 & 11.11 \\
\hline 5 & 75.275 & 76.344 & 7 & 38.89 \\
\hline \multicolumn{3}{|c|}{ Jumlah } & 18 & 100.00 \\
\hline
\end{tabular}

Tabel di atas, menunjukkan bahwa terdapat sebanyak 3 orang $(16,67 \%)$ berada pada kelompok $70.995-72.064,1$ orang $(5.56 \%)$ berada pada kelompok $72.065-73.134,5$ orang $(27.78 \%)$ pada kelompok 73.135-74.204, 2 orang $(11,11 \%)$ berada pada kelompok 74.205-75.274, dan 7 orang (38.89\%) berada pada kelompok 75.27576.344. Untuk lebih jelasnya penjabaran distribusi frekuensi di atas dapat dilihat pada histogram berikut:

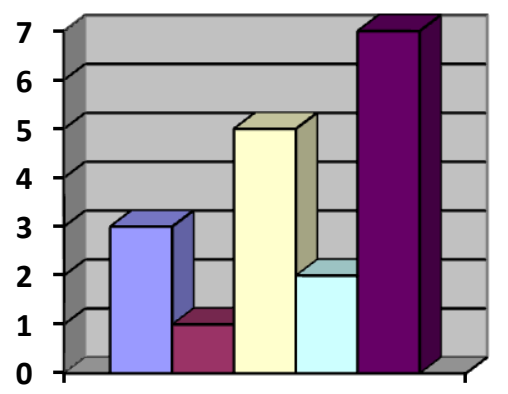

\begin{tabular}{|l|}
\hline $70.995-72.064$ \\
$\square 72.065-73.134$ \\
$\square 73.135-74.204$ \\
$\square 74.205-75.274$ \\
$\square 75.275-76.344$ \\
\hline
\end{tabular}

Histogram Keterampilan Jurus Tunggal Pencak Silat Diberi Metode Pembelajaran Komando pada Kategori Kemampuan motorik Tinggi $\left(\mathbf{A}_{2} \mathbf{B}_{1}\right)$

8. Hasil Keterampilan Jurus Tunggal Pencak Silat Kelompok Diberi Metode 
Pembelajaran Komando pada Kategori Kemampuan motorik Rendah $\left(\mathbf{A}_{2} \mathbf{B}_{2}\right)$

Data hasil pengukuran sampel dalam kelompok ini terdiri dari 18 Sampel $(\mathrm{n}=18)$ dengan skor tertinggi 80.67, skor terendah 67.67, dan jarak pengukuran (range) 13. Rerata skor 76.40, simpangan baku 3.47, median 76.66 dan modus 76.00. Distribusi frekuensi Sampel kelompok dengan banyak kelas 5 dan panjang kelas 2.60 dapat digambarkan dalam tabel distribusi frekuensi berikut:

Distribusi Frekuensi Keterampilan Jurus

Tunggal Pencak Silat Diberi Metode

Pembelajaran Komando pada Kategori

Kemampuan motorik Rendah $\left(\mathbf{A}_{2} \mathbf{B}_{2}\right)$

\begin{tabular}{|c|c|c|c|c|}
\hline $\mathrm{N}$ & \multicolumn{2}{|c|}{ Kelas Interval } & \multicolumn{2}{c|}{ Frekuensi } \\
\cline { 4 - 5 } $\mathrm{o}$ & & $\mathrm{F}$ & $\%$ \\
\hline 1 & 67.665 & 70.274 & 1 & 5.56 \\
\hline 2 & 70.275 & 72.884 & 2 & 11.11 \\
\hline 3 & 72.885 & 75.494 & 3 & 16.67 \\
\hline 4 & 75.495 & 78.104 & 6 & 33.33 \\
\hline 5 & 78.105 & 80.714 & 6 & 33.33 \\
\hline \multicolumn{3}{|c|}{ Jumlah } & 18 & 100.00 \\
\hline
\end{tabular}

Tabel di atas, menunjukkan bahwa terdapat sebanyak 1 orang $(5.56 \%)$ berada pada kelompok 67.665-70.274, 2 orang (11.11\%) berada pada kelompok $70.275-72.884,3$ orang (16.67\%) pada kelompok 72.885-75.494, 6 orang (33.33\%) pada kelompok 75.495-78.104, dan 6 orang (33.33\%) berada pada kelompok 78.10580.714. Untuk lebih jelasnya, penjabaran distribusi frekuensi di atas dapat dilihat pada histogram berikut:

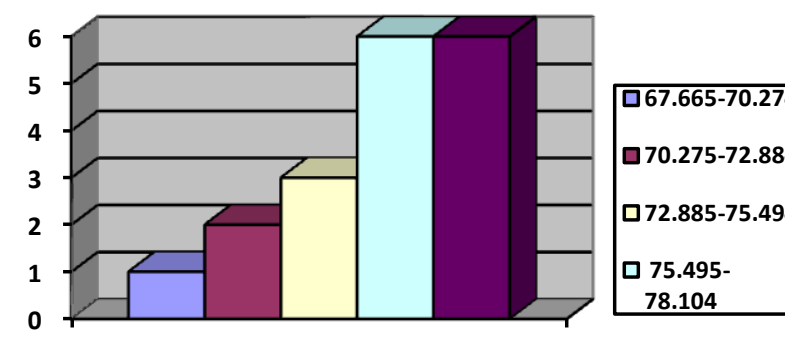

\begin{abstract}
Histogram Keterampilan Jurus Tunggal Pencak Silat Diberi Metode Pembelajaran Komando pada Kategori Kemampuan motorik Rendah $\left(\mathbf{A}_{2} \mathbf{B}_{2}\right)$
\end{abstract}

\section{Pembahasan}

\section{Perbedaan Keterampilan Jurus Tunggal Mahasiswa diberi Metode Inkuiri dan Komando}

Hasil pengujian hipotesis pertama menunjukkan bahwa secara keseluruhan, skor keterampiln jurus tunggal pencak silat mahasiswa diberi metode pembelajaran Inkuiri lebih tinggi sebesar 76.55 dibanding dengan metode pembelajaran Komando sebesar 75.15. Dengan kata lain bahwa hipotesis penelitian yang diajukan diterima. Dari hasil temuan ini dapat dikemukakan bahwa metode pembelajarn yang diberikan dengan Metode Inkuiri hasilnya akan lebih efektif dibandingkan dengan metode pembelajaran yang diberikan dengan metode Komando.

Sebagaimana telah dikemukakan pada kajian teori sebelumnya bahwa metode Inkuiri akan menjadi efektif dalam meningkatkan Keterampilan Jurus Tunggal Pencak Silat mahasiswa, karena pembelajaran metode Inkuiri memberikan kebebasan kepada mahasiswa untuk bergerak dan aktif dalam proses pembelajaran. Mahasiswa bisa menjelajahi gerakan yang disampaikan oleh dosen dalam pembelajaran jurus tunggal pencak silat, mahasiswa tersebut akan menemukan gerakan yang sesuai dengan pembelajaran yang disajikan. Dalam metode pembelajaran Inkuiri ini mahasiswa juga di tuntut agar mampu bekerja sama dengan sesama teman satu sama lainnya, karena itu juga proses pembelajarn berpusat pada mahasiswa. Sedangkan peran Dosen hanya sebagai fasilitator dan motivator.

Metode pembelajaran Komando proses pembelajaran berpusat kepada Dosen. Dosen lebih banyak aktif dalam proses pembelajaran, sedangkan para mahasiswa hanya bersifat menunggu perintah atau komando yang diberikan oleh Dosen. Peran mahasiswa dalam pembelajaran metode Komando ini mengikuti atau melaksanakan, serta mematuhi perintah yang diberikan oleh Dosen selama pembelajaran berlangsung.

Memilih metode pembelajaran dalam memulai sesuatu proses pembelajaran merupakan suatu hal yang penting dilakukan untuk mencapai tujuan pembelajaran supaya tercapai KKM (kriteria ketuntasan minimal) yang ditargetkan dalam rancangan pembeljaran. Seperti yang dikutip Alnedral (2008:15) bahwa metode mengajar dirancang dalam berbagai corak (spektrum) yang disebut dengan spektrum metode mengajar. Masing-masing metode mengajar mempunyai nilai yang lebih besar ditandai pada cara mengajar kreatif yang bertingkat. Kreatif tersebut dianggap target untuk kebebasan 
pencapaian kemampuan individu dalam proses metode pengajaran.

Perbedaan kedua Metode pembelajaran yang diberikan dengan Inkuiri dan metode pembelajaran Komando. yang diberikan kepada mahasiswa ternyata hasilnya lebih efektif Metode pembelajaran Metode Inkuiri .

\section{Interaksi Antara Metode Pembelajaran dengan Kemampuan motorik.}

Hasil yang berkaitan dengan pengujian hipotesis interaksi, membuktikan bahwa terdapat interaksi antara Metode pembelajaran dengan Kemampuan motorik dalam pengaruhnya terhadap Keterampilan Jurus Tunggal Pencak Silat mahasiswa, atau dengan kata lain bahwa hipotesis penelitian yang diajukan teruji kebenaranya.

Pada kelompok Kemampuan motorik tinggi yang diberikan Metode Mahasiswa FIK UNP pembelajaran inkuiri memperoleh skor yang lebih tinggi dibandingkan dengan kelompok Sampel dengan kategori Kemampuan motorik rendah yang diberikan Metode pembelajaran Inkuiri. Dengan demikian, berarti bahwa terjadi pengaruh interaksi antara Metode pembelajaran dengan Kemampuan motorik terhadap Keterampilan Jurus Tunggal Pencak Silat. Dapat diartikan bahwa Metode pembelajaran terhadap Keterampilan Jurus Tunggal Pencak Silat tergantung pada Kemampuan motorik anak tersebut.

Terjadinya interaksi antara Metode pembelajaran dengan kemampuan motorik sebagaimana yang dijelaskan di atas dapat digambarkan memalui perbandingan rendah keempat kelompk sampel antara Metode pembelajaran dengan kemampuan motorik tinggi dan kemampuan motorik rendah yang diberikan Metode pembelajaran yang berbeda sebagai berikut:

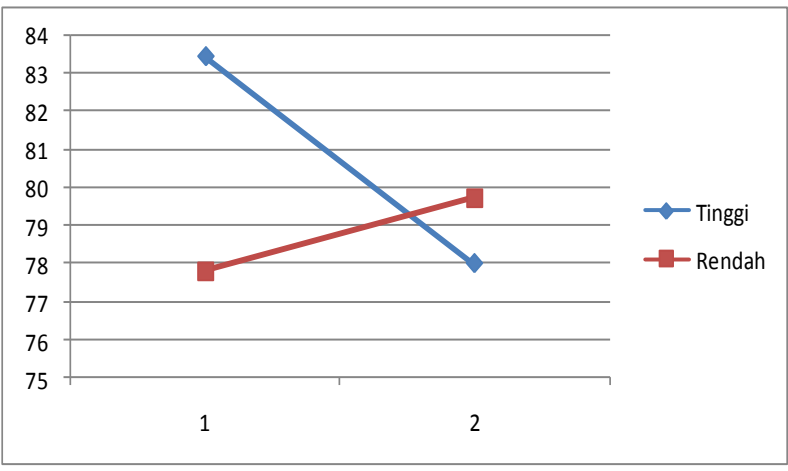

Interaksi Metode Pembelajaran dengan Kemampuan motorik
Memperhatikan grafik di atas dapat dilihat perbedaan yang cukup signifikan antara Metode pembelajaran Inkuiri yang diberikan pada kelompok sampel dengan kemampuan motorik tinggi dan yang diberikan pada kelompok sampel dengan kemampuan motorik rendah. Demikina juga dengan Metode pembelajaran Inkuiri yang diberikan dengan kemampuan motorik tinggi dan yang diberikan dengan kemampuan motorik berprstasi rendah.

Menurut Alnedral (2008:16) Untuk mencapai sasaran yang optimal dalam proses pengajaran perlu adanya Metode dalam pengajaran yang diterapkan oleh guru agar terjadi interaksi pengajaran. Pilihan metode biasanya didasarkan pada kondisi belajar seperti kebutuahn siswa, besarnya kelas, fasilitas yang tersedia, perlengkapan yang dimiliki, tujuan yang ingin dicapai, serta pokok bahasan.

Hamzah (2006:47) menjelaskan bahwa kemampuan motorik menekankan kepada tujuan pencapaian kebutahan yang tinggi seperti; selera akan keadaan yang menyebabkan seseorang dapat bertanggung jawab secara pribadi, kecendrungan menentukan sararan-sasaran yang akan dicapai dengan memperhitungkan resikonya, dan keingin untuk mendapatkan umpan balik yang jelas atas apa yang dilakukannya.

Menurut pendapat teori di atas jelas Metode pembelajaran membutuhkan kemampuan motorik untuk mencapai keterampialan gerak dasar. Untuk mewujudkan keinginan anak mendapatakan sesuatu dalam kemampuan motorik perlu adanya Metode pembelajaran yang akan kita berikan kepada anak tersebut. Hal ini disebabkan Metode pembelajaran membutuhkan interaksi dan mencerminkan perilaku mengajar dan belajar dalam kemampuan gerak dasar, seorang guru bisa melihat kemampuan motorik dari peserta didik, kerana menyangkut dengan Metode pembelajaran yang akan diberikan oleh guru supaya sasaran pembelajaran kemampuan gerak dasar yang diharapkan bisa tercapai

3. Perbedaan Keterampilan Jurus Tunggal Pencak Silat Mahasiswa Memiliki Kemampuan motorik Tinggi Diberi Metode Inkuiri dengan Metode Komando

Hasil pengujian hipotesis ketiga menunjukkan bahwa secara keseluruhan, skor keterampilan jurus tunggal pencak silat mahasiswa memiliki kemampuan motorik tinggi diberi metode pembelajaran inkuiri sebesar 83.00 lebih tinggi dibanding dengan metode pembelajaran komando sebesar 74.28. Dengan 
kata lain, bahwa hipotesis penelitian yang diajukan diterima. Dari hasil temuan ini dapat dikemukakan bahwa metode pembelajaran inkuiri lebih efektif digunakan dari pada metode pembelajaran komando pada Kemampuan motorik tinggi.

Alnedral (2008:26) inti sari dari Metode Inkuiri adalah hubungan segera dan langsung antara rangsangan yang diberikan oleh pengajar dapat direspon langsung oleh mahasiswa. Setiap gerakan yang ditampilkan melalui demontrasi yang diberikan oleh guru, kemudian setiap keputusan mengenai lokasi, postur, waktu mulai, bentuk dan irama, waktu berhenti, durasi, dan interval dibuat oleh pengajar.

Pembelajaran Metode Komando pada kelompok mahasiswa yang memiliki kemampuan motorik tinggi, kemampuan mahasiswa untuk mendapatkan Keterampilan Jurus Tunggal Pencak Silat akan lebih baik dari pembelajaran Metode Inkuiri karena anak berfikir kearah yang lebih baik berkaitan dengan bagaimana kemampuan gerak dasar yang mereka miliki. Saat mereka telah melakukan suatu satuan pembelajaran kemampuan gerak dasar, mereka akan melakukan koreksi terhadap gerakan yang dilakukan, dan akan mencobakan kembali gerakan dengan harapan gerakan yang dilakukan selanjutnya akan lebih baik.

Sedangkan pembelajaran Metode Komando pada kelompok anak yang kemampuan motorik tinggi, kemampuan anak untuk mendapatkan Keterampilan Jurus Tunggal Pencak Silat hasilnya akan kurang baik dengan pembelajaran Metode Komando karena anak di gerakan di awasi oleh guru. Akibatnya gerakan yang dilakukan oleh anak yang mempunyai kemampuan motorik tinggi akan tertunta perkembanga gerakannya. Anak selalu menunggu aba-aba serta perintah dari guru dalam memulai suatu gerakan yang diberikan untuk kemampuan gerak dasar, sehingga anak tidak menemukan gerakan yang sesuai dengan keteria kemampuan gerak dasar karena setiap anak melakukan gerakan selalu dipantau dan dilihat oleh guru.

Berdasarkan hasil analisis data, maka siswa yang memiliki Kemampuan motorik tinggi pada kelompok yang diberi Metode pembelajaran Inkuiri mampu meningkatkan Keterampilan Jurus Tunggal Pencak Silat yang lebih baik.
4. Perbedaan Keterampilan Jurus Tunggal Pencak Silat Mahasiswa Memiliki Kemampuan motorik Rendah Diberi Metode Inkuiri dan Metode Komando

Hasil pengujian hipotesis keempat menunjukkan bahwa secara keseluruhan, skor pembelajaran kelompok yang diberikan Metode Komando lebih rendah sebesar 70.15 dari pada yang diberikan Metode Inkuiri pada Kemampuan motorik rendah sebesar 76.41. Dengan kata lain bahwa hipotesis penelitian yang diajukan diterima. Dengan kata lain bahwa hipotesi yang diajukan teruji kebenarannya secara signifikan. Dari hasil temuan ini dapat dikemukakan bahwa Metode pembelajaran inkuiri lebih efektif digunakan untuk mahasiswa yang berkemampuan motorik tinggi dari pada Metode Komando pada Kemampuan motorik rendah. Seperti yang dijelaskan Alnedral (2008:26) sebagai berikut:

Sedangkan pembelajaran yang diberikan metode inkuiri, bagi mahasiswa yang memiliki kemampuan motorik tinggi hasilnya lebih efektif, karena mereka yang memiliki kemampuan motorik tinggi akan lebih bebas melakukan gerakan jurus tunggal pencak silat sesuai ide dan kreativitas mareka. Mereka lebih cendrung aktif terhadap materi yang diberikan disebabkan oleh kemampuan motoriknya yang lebih tinggi.

Berdasarkan analisis data mahasiswa, metode pembelajaran Inkuiri lebih efektif dibandingkan dengan metode pembelajaran komando bagi anak yang memiliki kemampuan motorik tinggi.

Unsur-unsur khas yang ada dalam pengajaran Metode Komando adalah: (1) semua keputusan dibuat oleh guru, (2) menuruti petunjuk dan melaksanakan tugas adalah merupakan kegiatan utama bagi siswa, (3) menghasilkan tingkat kegiatan yang tinggi, (4) dapat membuat siswa terasa terlibat dan terkemampuan motorik, (5) mengembangkan perilaku berdisiplin karena harus mentaati prosedur yang telah ditetapkan oleh guru dalam pembelajaran.

Terdapat beberapa implikasi dalam penggunaan Metode Komando antar lain: (1) standar penampilan sudah mantap dan pada umumnya satu model untuk satu tugas, (2) pokok pelajaran dipelajari secara meniru (imitasi) mengingat melalui penampilan, (3) pokok pembahasan dipilih-pilih menjadi bagian-bagian yang dapat ditampilkan oleh guru agar bisa ditiru siswa, (4) tidak ada perbedaan individual, diharapkan semua menirukan model yang disajikan oleh dosen.

Berdasarakn pendapat teori tersebut dapat diartikan bahwa Metode pembelajaran kamando memang cocok diberikan kepada mahasiswa yang memiliki kemampuan motorik rendah, karena 
mulai dari persiapan memulai pemebalajaran sampai akhir pembelajaran mahasiswa yang memiliki kemampuan motorik rendah selalu menuruti petunjuk melaksanakan tugas yang diperintahkan oleh dosen. Dalam metode pembelajaran komando ini semua mahasiswa dapat melakukan dan melaksanakan tugas gerakan pembelajaran yang diberikan secara serempak dan tidak ada perbedaan individual.

\section{Kesimpulan}

Berdasarkan temuan penelitian dan pembahasan hasil penelitian maka dapat disimpulkan sebagai berikut:

1. Metoda pembelajaran Inkuiri lebih efektif digunakan untuk meningkatkan keterampilan Jurus Tunggal Pencak Silat mahasiswa dari pada metoda pembelajaran komando.

2. Terdapat interaksi antara metoda pembelajaran dengan Kemapuan Motorik terhadap peningkatan Jurus Tunggal Pencak Silat mahasiswa.

3. Pada tingkat Kemampuan Motorik tinggi, metoda pembelajaran Inkuiri lebih efektif daripada metoda pembelajaran komando untuk meningkatkan Jurus Tunggal Pencak Silat mahasiswa.

4. Pada tingkat Kemampuan Motorik rendah, metoda pembelajaran Komando lebih efektif dari pada metoda Inkuri untuk meningkatkan keterampilan Jurus Tunggal Pencak Silat mahasiswa

\section{DAFTAR PUSTAKA}

Corbin, Charles B. A Texbook of Motor Development. Towa: Wm C. Browen Company Publisher, 1980

Depdiknas. Cetak Biru Pembinaan dan Pengembangan Olahraga Pendidikan Terpadu Jangka Panjang 2010-2025. Jakarta: Depdiknas, 2009

Gabbard Carl, Elyzabeth LeBalanc, Susan Lowy. Physical Education for Children Building the Fundation. Englewood Clieffs, New Yersey: Prentice Hall, Inc., 1987

Gallahue L. David, dkk. A Conceptual Approach to Moving and Learning. New York: Jhon Eley \& Son. Inc., 1976
Understanding Motor Developmen in Children. New York: Macmilan Publishing Company, 1985

Gerlach, Vermon s. and Donald P.Ely. Teaching and Media: A Systematic Approach. Englewood Cliffts, NJ: Prentice-Hall, 1971

Godfrey, Catherine. Becoming a Physycal Education Teacher: Contempraryand enduring issues. Australia : Pearson Education Australia, 2001

Goodway, J.D., Crowe, H., \& Ward, P. Effects of Motor Skill Instruction on Fundamental Motor Skill Development, Adapted Physical Activity Quartly.Champeign, IL: Human Kinetics, 2003

Hurlock, Elizabeth B. Psikologi Perkembangan: Suatu Pendekatan Sepanjang Rentang Kehidupan- Edisi Kelima.Terjemahan Istiwidayanti. Jakarta: Pen. Erlangga, 1996

Iskandar, Model Latihan Pencak Silat Kategori Jurus Tunggal pada Cabang Olahraga Pencak Silat, (Disertasi), Jakarta: PPs. UNJ., 2013.

Joko Subroto, Dasar-dasar Pencak Silat, Solo: CV. Gunung Mas 1996

Kiram, Yanuar. Belajar Motorik. Jakarta: Depdikbud Dirjendikti P2TK., 1992

Kemampuan Koordinasi Gerak dan Klasifikasi Aktivitas Motorik dalam Olahraga. Padang: FPOK-IKIP., 1994

Lubis, Johansyah, Pencak Silat Panduan Praktis, Jakarta: PT RajaGrafindo Persada, 2004

Lutan, Rusli. Belajar Keterampilan Motorik, Pengantar Teori dan Metode. Jakarta: Depdikbud. Dirjenti. P2LPTK, 1988.

Margill, Richard A. Motor Learning and Control, Consepts and Applications- $9^{\text {th }}$ ed. . Singapore: New York University, 2011

Mosston, M and Ashwort, S. Teaching Physical Education- $5^{\text {th }}$ ed. New York: McMillan College Publishing, 2002 
Notosoejitno, Khasanah Pencak Silat. Jakarta: CV, Sagung Sewo.

Peters, R. S. The Concept of Education. London: Routledge \& Kegan Paul, 1973

Singer, Robert N., Motor Learning and Human Performance. An Application to Motor Skills and Movement Behaviors Third Edition.New York: Macmillan Publishing CO.,INC., 1980.

Sucipto, Pendekatan Keterampilan Taktis Dalam Pembelajaran Pencak Silat Konsep \& Metode. Jakarta Drektorat Jenderal Olahraga Depdiknas 2001

Sugiyanto dan Sudjarwo. Perkembangan dan Belajar Gerak. Jakarta: Depdikbud., 1991

Verducci, Frank M. Measurement Concept in Physical Education. St. Louis: Mosby Company, 1980. 